\title{
Endgame: The false destruction of the social imaginary
}

\author{
Nina Boy \\ Heidelberg University, Germany
}

How is it possible that the Capitol attack of January 2021 was frameable as a "normal tourist visit" by Congressman Representative Andrew S. Clyde ${ }^{1}$ How could naming the event an insurrection itself be called a "boldfaced lie" despite the evidence conveyed in widespread live media coverage? If such denial once seemed to belong to the fringes of society, subject to Louis Theroux's exploration of the "genuinely odd" in the BBC series Weird Weekends, it now forms a central battleground across liberal democracies that liberals continue to look out onto incredulously, and helplessly.

It is the conditions of possibility for this crisis of factuality - and its consequences for power, democracy, and society - that Joseph Vogl traces in his latest book, Capital and Ressentiment (2021/2022). In many ways, Vogl's analysis thus reads as a sequel to Mary Poovey's (1998) History of the Modern Fact. If Poovey conveyed how facts acquired the status of neutral description of the world, independent from political, moral, or theological argument, Vogl imputes the loss of this epistemic authority to the effective fusion of financialization and the platform economy. The key driving force of what he terms opinion markets is identified in the parameter of information which becomes severed from cumbersome ties to logics of reason and justification.

The result is not so much a shift in episteme, but rather a shift from (liberal) epistemology to capitalist ontology whereby the principle separation underlying epistemology, between knowledge and reality - the very separation, that is, that renders knowledge falsifiable - is undone. Instead, the critical difference lies between existing expectations and the unexpected - where the more unlikely or absurd, the greater its informational value. This coincidence of ontology and capital means that the representation of the world cannot be divorced from its evaluation and validation: "Reality itself has taken on the character of an intrusive value form" (Vogl, 2021b: 135).

Synthesizing vast stretches of state-of-the-art literature, Vogl's analysis reveals the coherence between seemingly disparate phenomena: from the expansion of 'zones of ignorance' amid an explosion of information (cf. Davies and McGoey, 2012); to why the UK's 'Leave' vote may still be read as an elemental affect of capitalism, despite its defiance of

\section{Corresponding author:}

Nina Boy, Centre for Apocalyptic and Post-Apocalyptic Studies (CAPAS), Berliner Str. 43, 69120 Heidelberg, Germany. Email: Nina.Boy@warwick.ac.uk. https://doi,org/10.2218/finsoc.v7i2.6654 
economic self-interest; to the ultimate conformism of the 'uproar' of ressentiment, which leaves systemic conditions unchallenged. Rather than a pathology on the fringes, populist ressentiment acquires an intensified structural function in information capitalism which then entails two parallel moves. In the same measure that information has detached itself from grounds of reasoning and platforms divested themselves of their responsibility for content with the 1996 Communications Decency Act, so does ressentiment in turn ascribe and attach blame to placeholder villains. "Seeming evidence", "illusions of reference" (Vogl, 2021a: 58) and "causal reflexes" (Vogl, 2021b: 124), however, follow a pseudological - and pathological structure: ressentiment is neither willing to nor capable of engaging in a genuine search for causes; it is as immune to contradiction as it is susceptible to contagion.

Next to the historical-epistemological account of the demise of factuality via Hayek, Keynes, and modern finance theory, a key element of the book's argument - at once understated and somewhat underdeveloped - lies in a second strand: the "direct connection" of our present condition to Herman Melville's final novel, The Confidence-Man: A Masquerade (1984/1857). Because ultimately, the "analysis of profitable truth games" can be less expected from discourses that fabricate and defend economic laws than from those who "by necessity observe, process, reflect and verify the functions and strategies of fabrication itself" (Vogl, 2021a: 145-46) - that is, literary expertise, and also Vogl's own as literary critic.

Set on a steamboat travelling the Mississippi River, the novel consists of an episodic series of encounters of its passengers who represent a public made up of tricksters and dupes. Departing on the designated Fool's Day (1 April), the journey of this ship of fools is marked by business transactions where demands for verification are rendered pointless and 'confidence' is produced by taking things at face value. It is here, Vogl surmises, that we can grasp the "pseudological structure" of the financial truth game and its equivalences of certitudes, equally valid as they are equally baseless (Vogl, 2021a: 152). Credit and certitude are not produced merely by neglecting evidence, but established through the "deliberate disavowal" of verification (Vogl, 2021a: 152) - a mechanism that brings to mind the famous attribute of safe assets to be taken at face value with "no questions asked" (cf. Gorton, 2016). The broken relation between signifier and signified not only indicates a trend of "mere lies", but something more severe: it testifies to the "stabilization of a discourse in which the criterion and difference of swindle and lie themselves have been annulled" (Vogl, 2021a: 155). In the pseudological affirmation, there is nothing left to underwrite or guarantee reality.

What Vogl thus suggests - though does not spell out - is that a full understanding of our present condition requires the kind of knowledge produced by fiction and those who study it. But what kind of knowledge is that, and how does it escape the capitalist ontology of information? How is it that we can find here a valuable ingredient for a theory of the present and how do the two strands of the argument relate? More could have been made of the significance of the book's genre - or "generic slipperiness" - from "comic allegory", to "withering satire of established epistemological, ethical and political beliefs", to "masterpiece of irony and control", to the culmination of "Melville's quarrel with fiction" and the ongoing question of whether it really was a novel (Duquette, 2019: 96). What does it mean if a satirical depiction, that is, the pointed exaggeration of financial realities, ${ }^{2}$ has become merely a description of reality? The fading grip of satirical critique as it is increasingly taken at face value must be seen as the mirror image of fake news, struggling to distinguish its deliberate distortion of reality from the latter, and its intention to reveal from the intention to conceal. The only reference to genre Vogl makes is to The Confidence-Man's "realism", meaning the novel's ability to tell the "denial of the real" through its "grasp of financial-economic realities" (Vogl, 2021a: 154). And these are characterized by truthiness, rather than verisimilitude - that is, a 
point of indifference between knowledge and belief, the performance of "truth sentiments" and the fabrication of a special variant of "truth-telling" whose status and effect is marked by a kind of credit derived from the rejection of verification (Vogl, 2021a: 143, 144). Trust and knowledge appear as very opposites: the demand for proof already indicates a crisis of credit.

However, the "cunning of ressentiment-driven reason" goes further than this, as Vogl shows in the final chapter of Capital and Ressentiment. The disparate social monads that Vogl arrives at here are not merely self-referential echo chambers, but constitute one another via operations of mutual displacement and discredit. Despite the capitalist 'conformism' of ressentiment, this strikes a radically new tone in the constitution of financial society that goes to the heart of its public credit. To illustrate this, a different fictional expertise may be drawn on here: Hans Christian Andersen's folktale, the Emperor's New Clothes, and Susanne Lüdemann's (2002) Derridean reading of it.

Contrary to conventional accounts of the well-known tale as paradigmatic topos of the unmasking of truth, Lüdemann's reading reveals how the cunning of the weavers - the tale's confidence men - ultimately ensures social cohesion. While the text sides with the point of view of the innocent child - the unbiased observer, protagonist of modernity and self-evident reference of language - it also, and herein lies its fictional expertise, shows the assumption of the identity of word and object to be naïve. If the plot seems to bring into play a number of clear oppositions: visible/invisible, seeing/not-seeing, truth/fraud, nakedness/dress, exposure/ disguise, loyal/disloyal, legitimate/illegitimate, and so on, it is "devised in such a way that all oppositions - including that of truth and fiction - become undecidable in the course of the tale" (Lüdemann, 2002a: 99). Insofar as the statement of the child is only supported by the text itself - calling a fraud a fraud - the truth is exposed in a text that itself constitutes a warning against rhetorical deceit: the Emperor's new clothes are literally "woven of words" by the frauds' fictive descriptions. The "text deconstructs itself by warning against itself" (Ursula Haselstein quoted in Lüdemann, 2002a: 100), thus undermining the claim to truth of the child. And yet it also tells the truth about the necessarily imaginary element of social cohesion and "perfectly stages the social dynamic that creates reality (here the emperor's dress) as an effect of belief in it - or belief in the belief of others that creates social consistency" (Lüdemann, 2002a: 99). So far, the tale corresponds with the insight of the Keynesian beauty contest, on which Vogl draws in his notion of opinion markets.

A second, critical factor for social cohesion however follows from the cunning stipulation of the tricksters that the Emperor's dress reveals another truth: it is only visible to loyal subjects or legitimate sons of their father. Not only does this grant the sovereign in turn a normative, Schmittian truth position (auctoritas, non veritas facit legem) to tell truth from fraud and the authentic from pretence (Lüdemann, 2002a: 100). It also means that his subjects are only able to tell the truth by risking their 'public credit' and exposing themselves as 'unfit for office'. The tale thus reveals the "naked truth that the truth always appears in social garment, is intersubjectively produced and never naked [...] the 'good subject' sacrifices reference to belonging" (Lüdemann, 2002a: 100-101). Lüdemann (2002b: 189) points to the "strangely unnoticed fact that the intervention of the child bears no social consequences", such as revolution or even laughter. With the Emperor's last words "I must go through with the procession" the tale ends in a "peculiar akenesia - as if something makes the perception of nakedness both possible and impossible, valid and invalid, legitimate and illegitimate" (Lüdemann, 2002b: 189). Ultimately, then, the tale is about the inconsequence, or at least ambivalence, of debunking truth, and illustrates the "tacit consent to deny the nakedness of the emperor and retain the Emperor's new clothes [as social fetish] intact" (2002b: 190-91). 
If the cunning of the weaver confidence-men lies in a clever interlocking of personal and sovereign public credit that secures social cohesion, the cunning of ressentiment-driven reason does quite the opposite. In stigmatizing the formal character of representative institutions as "false or falsifying, be they elections or parliaments, "elites' or the "press'" (Vogl, 2021b: 125), it turns the very source of credit and legitimacy - mediation, representation, accredited institutions - against itself and into a source of discredit. Here Vogl echoes William Davies' observation of a

rebellion against systems of representation of one kind or another - an unmasking of our 'representatives' as nothing but self-interested cynics and hypocrites. The relationships between political representatives and the people, between 'mainstream media' and actual events, between science and reality, all become viewed as a scam. (Davies, 2018: 37)

This crisis of representation and attack at once on its formal and epistemic institutions is by no means reserved for the right-wing, but pits 'woke' dissociation - such as in declarations of 'Not in my name' - against its 'awake' counterpart. The post-truth condition of ressentiment thus effects a significant reversal of the financial truth game of Melville's Confidence-Man. Instead of drawing credit from the rejection of evidence, it finds evidence in non-existence: "Where are all the dead bodies from all the Covid tests?" asks a character in a comic in the German newspaper Zeit Online. "You don't hear anything about that. That is very suspicious. This really should ring the alarm bells for everyone" (Kling and Kissel, 2021). The fact that the dead bodies are nowhere to be found is taken as proof for their existence. Likewise, this reverses the societal truth game of the Emperor's New Clothes. Declaring the formal or representative as false does not mean that ressentiment takes the Emperor's nakedness, that is, the non-existence of the dress, as proof for its existence; it meets the cunning of the imaginary investment of power with its own cunning divestment. Instead of the often conflated condition of the postmodern and post-truth, here is a new genre of ontological fiction that destroys, rather than underwrites, social cohesion, rendering even the postmodern interpretation of power naïve.

The dystopian note of a prewar era that Vogl ends on brings home the point that we find ourselves at a turning point. But his self-admittedly "apotropaic gesture" 3 - a warning and attempt to summon the power to avert evil - signifies more than that: it extends to the imperilled status of the humanities, which after a brief moment in the limelight following the interest in 'financial fictions' sparked by the global financial crisis, are leading an increasingly ghostly existence. Vogl's new book may well be a last rearing up of this tradition, demonstrating the subtle grasp, perception, and scope of an expertise that is itself fighting for life.

\section{Notes}

1. This work has been enabled by a fellowship at the Centre for Apocalyptic and Post-Apocalyptic Studies (CAPAS) at Heidelberg University. All direct quotes from Vogl (2021a), Lüdemann (2002a/ 2002b) and Kling and Kissel (2021) are my own translation.

2. And one whose warning failed to impress contemporaries; the book was such a failure that Melville abandoned writing fiction for twenty years. Only in the twentieth century did critics celebrate its "technical virtuosity, wit, comprehensive social vision, and wry skepticism". From the back matter on Melville, 1984; available at <https://nupress.northwestern.edu/9780810103252/ the-confidence-man/>. 
3. Interview with Joseph Vogl on Soziopolis.de, March 18, 2021. Available at: <https:// www.soziopolis.de/eine-neue-kapitalistische-ontologie.html>.

\section{References}

Davies, W. and McGoey, L. (2012) Rationalities of ignorance: On financial crisis and the ambivalence of neo-liberal epistemology. Economy and Society, 41(1): 64-83.

Davies, W. (2018) Nervous States: How Feeling Took Over The World. London: Jonathan Cape.

Duquette, E. (2019) The Confidence-Man between genres. In: Marrs, C. (ed.) The New Melville Studies. Cambridge: Cambridge University Press, 96-113.

Gorton, G. (2016) The history and economics of safe assets. SSRN, 31 August. Available at <https:// ssrn.com/abstract=2770569>. Accessed 13 December 2021.

Kling, M.-U. and Kissel, B. (2021) Känguru-Comic No. 297 Alarmglocken. Zeit Online, 9 December. Available at: <https://www.zeit.de/kaenguru-comics/2021-12/folge-297>. Accessed 13 December 2021.

Melville, H. (1984) The Confidence-Man: His Masquerade [1857]. Evanston, IL: Northwestern University Press.

Lüdemann, S. (2002a) Die nackte Wahrheit. In: Frank, T. et al (eds.) Des Kaisers neue Kleider: Über das Imaginäre politischer Herrschaft. Frankfurt a. M.: Fischer, 95-102.

Lüdemann, S. (2002b) Fetischismus. In: Frank, T. et al (eds.) Des Kaisers neue Kleider: Über das Imaginäre politischer Herrschaft. Frankfurt a.M.: Fischer, 187-96.

Poovey, M. (1998) A History of the Modern Fact: Problems of Knowledge in the Sciences of Wealth and Society. Chicago, IL: University of Chicago Press.

Vogl, J. (2021a) Kapital und Ressentiment: Eine kurze Theorie der Gegenwart. München: C.H. Beck.

Vogl, J. (2021b) Capital and ressentiment: The totalizing power of social fragmentation. Finance and Society, 7(2): 123-28.

Vogl, J. (2022) Capital and Ressentiment, translated by N. Solomon. Cambridge: Polity. 